\title{
New Oncolytic Adenoviruses with Hypoxia- and Estrogen Receptor-Regulated Replication
}

\author{
RUBEN HERNANDEZ-ALCOCEBA, MICHAEL PIHALJA, DALONG QIAN, and MICHAEL F. CLARKE
}

\begin{abstract}
Oncolytic adenoviruses with restricted replication can be produced if the expression of crucial transcription units of the virus is controlled by tissue- or tumor-specific promoters. Here we describe a method for the rapid incorporation of exogenous promoters into the E1A and E4 regions of the human adenovirus type 5 genome. Using this system, we have generated AdEHT2 and AdEHE2F, two conditionally replicative adenoviruses for the treatment of breast cancer. The expression of the E1A gene in both viruses is controlled by a minimal dual-specificity promoter that responds to estrogens and hypoxia. The tight regulation of E1A expression correlated with the ability of these viruses to replicate and kill human cancer cells that express estrogen receptors, or are maintained under hypoxic conditions. The telomerase reverse transcriptase (TERT) promoter and the E2F-1 promoter are preferentially activated in cancer cells. They were introduced into the E4 region of AdEHT2 and AdEHE2F, respectively. The telomerase core promoter failed to block the replication of the virus in telomerase-negative cells. In contrast, AdEHE2F was attenuated in nontransformed quiescent cells growing under normoxic conditions, suggesting that an intact pRB pathway with low levels of E2F transcription factors acts as a negative modulator for the virus. These data indicate that the simultaneous regulation of E1A and E4 viral transcription units by the appropriate combination of promoters can increase the tumor selectivity of oncolytic adenoviruses.
\end{abstract}

\section{OVERVIEW SUMMARY}

The lytic cycle of adenovirus leads to the death of the infected cells and the liberation of thousands of new viral particles. These properties can be exploited for the generation of therapeutic agents against cancer, if the replication of the virus is redirected to the malignant tissues. Three common characteristics found in most solid tumors are the existence of hypoxic areas, the expression of telomerase in the cells, and the elevation in free E2F transcription factors due to alterations in the pRB pathway. We have tested a combination of promoters that are activated under these circumstances in order to control the expression of regulatory proteins of adenovirus. We found that control of the viral E1A region by a hypoxia-responsive promoter and, to a lesser extent, control of the $\mathrm{E} 4$ region by an E2F-responsive promoter allow preferential replication of adenovirus in solid tumors.

\section{INTRODUCTION}

$\mathbf{T}$ THE NEW GENERATION of conditionally replicative adenoviruses (CRADs) represents an advance over the previous replication-deficient vectors used in gene therapy against cancer. The ability to replicate their genome after infection allows them to amplify the effect that an initial load of vector may have. More importantly, they are therapeutic agents by themselves because they retain the ability to kill the cells as the last step of their lytic cycle (Alemany et al., 2000). There are two major approaches to achieve preferential replication of adenovirus in cancer cells (Kruyt and Curiel, 2002). The so-called type 1 CRADs are based on the deletion or functional disruption of viral genes that activate the cell cycle in the infected cell, an effect that is needed for replication of the viral genome. This idea led to the development of $d l 1520$, the first and most extensively used oncolytic adenovirus (Kirn, 2001; Biederer et al., 2002). It contains a deletion in the E1B-55 kDa gene, which

Department of Internal Medicine, University of Michigan Comprehensive Cancer Center, Ann Arbor, MI 48109. 
is essential for the virus to inactivate $\mathrm{p} 53$ and force the infected cell to enter the $S$ phase of the cell cycle (Bischoff et al., 1996). As a result, $d l 1520$ shows preferential replication in those cells that have the p53 and related pathways already compromised by different mechanisms (Ries et al., 2000; Yang et al., 2001), as is the case in the majority of cancer cells. In accordance with the same principle, an adenovirus with a small deletion in the E1A gene targets cells with defects in the pRB pathway (Fueyo et al., 2000; Heise et al., 2000). However, these viruses are often attenuated even in the target cells, because the deletions can affect other functions of these viral genes. More recently, an alternative method to achieve tumor specificity has been described (Ramachandra et al., 2001). The authors constructed a replication-competent adenovirus that expresses a repressor of E2F activity under the control of a promoter that responds to p53.

The second strategy to develop CRADs is based on the transcriptional control of genes that are necessary for replication of the virus. The viral genes are not modified; rather, they are placed under the control of promoters that are preferentially active in the tumor cells, compared with the surrounding tissues. E1A and E4 are the first two transcriptional units to be activated after infection, and both are required for efficient replication and viral production (Falgout and Ketner, 1987). The control of the E1A region is especially important because E1A acts as a strong activator for most of the transcription units in the adenovirus genome (Shenk, 1996). This means that if E1A is not expressed, not only is the virus unable to replicate, but also the expression of other viral proteins is greatly attenuated. The E4 region encodes a group of proteins that perform diverse functions and show a complex repertoire of interactions with other viral and cellular proteins (Tauber and Dobner, 2001). They are involved in replication of viral DNA, particle assembly, and interference with functions of the host cell such as competition for protein synthesis and induction of apoptosis (Halbert et al., 1985; Branton and Roopchand, 2001). This latter effect can be important for an adequate release of virions once the viral DNA has been encapsidated. Therefore, controlling simultaneously the expression of E1A and E4 genes achieves a tighter control over replication of the virus (Hernandez-Alcoceba et al., 2000; Fuerer and Iggo, 2002), and at the same time it decreases the risk of recombination and reversion to the wildtype genome. Promoters that have been used to control the E1A region include the prostate-specific promoter and enhancer for prostate cancer (Yu et al., 1999), the osteocalcin promoter for bone metastases (Matsubara et al., 2001), the midkine promoter for Ewing's sarcoma and neuroblastoma (Adachi et al., 2001), the $\alpha$-fetoprotein promoter for hepatocellular carcinomas (Hallenbeck et al., 1999), the surfactant protein B (SPB) promoter for lung cancer (Doronin et al., 2001), and promoters containing tcf/LEF transcription factor-binding sites for colon cancer (Fuerer and Iggo, 2002). These CRADs showed preferential replication in cancer cells, and demonstrated antitumor activity in preclinical models. However, for many human malignancies, including breast cancer, a tumor-specific promoter has not yet been characterized in detail. A CRAD utilizing the MUC-1 promoter in the $\mathrm{E} 1 \mathrm{~A}$ region has been made because this protein is overexpressed in many mammary tumors (Kurihara et al., 2000), but some normal tissues also express this protein (Brugger et al., 1999). In an initial approach to develop a CRAD for breast cancer, we constructed AdERE2 (Hernandez-Alcoceba et al., 2000), a recombinant adenovirus that has both the E1A and E4 promoters deleted and substituted by a portion of the pS2 promoter containing two estrogen response elements (EREs). The estrogen receptor (ER) binds to these sequences and exerts its function as a transcriptional activator (Ekena et $a l ., 1998)$. This means that estrogens can activate the promoter only in cells that express ERs, which is the case in up to $70 \%$ of human breast cancers (Valavaara, 1997). In AdERE2, both E1A and E4 were efficiently controlled by this promoter, and we showed preferential replication and killing of breast cancer cells expressing ERs. In addition, AdERE2 was able to complement in trans the E1A deficiency of a replication-defective adenovirus vector expressing the proapoptotic gene encoding Bcl-xs.

One of the advantages of using transcriptional control for the generation of CRADs is the possibility of combining different response elements in the same regulatory unit to create artificial multispecificity promoters. In addition, different transcription units can be separately regulated in the same virus. In this way, the virus can be activated by a combination of stimuli that resemble the conditions present in tumor tissues. Because of the complexity of the adenovirus genome, the performance of these combinations of promoters can be tested only when the actual virus is produced. To facilitate this process, we have engineered a plasmid that contains the adenovirus genome with unique restriction sites flanking the E1A and E4 promoter regions. We have used this backbone to produce the CRADs that we describe here.

One common characteristic of most solid tumors is that they grow in an environment of low oxygen tension (hypoxia), due to the their aberrant vasculature (Zhong et al., 1999; Talks et al., 2000). Virtually all the cells in an organism have mechanisms for sensing and responding to lack of oxygen and nutrients. The transcription factor HIF (hypoxia-induciblefactor) is an $\alpha / \beta$ heterodimer. The $\alpha$ subunit of this transcription factor is rapidly ubiquitinated and degraded by the proteasome under normoxic conditions, but the protein is stabilized in hypoxic environments (Huang et al., 1998). The high levels of HIF induce the expression of a repertoire of genes necessary for adaptation to low oxygen. HIF binds to a sequence in the promoter of these genes, named the hypoxia responsive element (HRE). The use of this sequence as an enhancer for the expression of therapeutic genes has been proposed for the treatment of solid tumors (Dachs et al., 1997). We have already described the characterization of a hybrid promoter containing HREs and EREs to control the expression of the proapoptotic gene harakiri (Hrk) (Hernandez-Alcoceba et al., 2001). This therapeutic cassette was evaluated with a replication-deficient adenovirus, and we showed specific induction of apoptosis in $\mathrm{ER}^{+}$breast cancer cells, or in any other cell growing under hypoxic conditions. In the present study, we have used a minimal artificial promoter containing EREs and HREs to control the expression of E1A in two different CRADs, AdEHT2 and AdEHE2F. We placed the $\mathrm{E} 4$ region of these viruses under the control of two different promoters that have shown great potential for cancer targeting. In AdEHT2, this transcription unit is controlled by the core human telomerase reverse transcriptase (hTERT) promoter. Telomerase is a ribonucleotide complex composed of an RNA template (hTR) and a catalytic protein subunit with re- 
verse transcriptase activity (hTERT) (Meyerson et al., 1997). This enzyme is necessary to maintain the ends of the chromosomes (telomeres), which cannot be replicated by DNA polymerase. Telomerase adds the hexameric sequence TTAGGG, preventing the shortening and destabilization of the chromosomes after multiple rounds of cell division (Greider, 1996). Interestingly, telomerase activity is not detected in most human somatic cells, but, in contrast, the expression of hTERT is reactivated in most human cancers, as well as germ line cells and probably stem cells (Harle-Bachor and Boukamp, 1996; Ulaner et al., 1998). The hTERT promoter has been characterized by different groups (Horikawa et al., 1999; Takakura et al., 1999; Wick et al., 1999), and it has already been used to selectively direct the expression of proteins to cancer cells (Komata et al., 2001; Majumdar et al., 2001). Because both E1A and E4 are necessary for efficient viral replication, we hypothesized that having this promoter in the E4 region could add a second level of tumor specificity to the virus.

In the case of AdEHE2F, we placed the E4 region of the virus under the control of the E2F-1 promoter. E2F-1 belongs to a family of transcription factors that are functionally active in the $G_{1} / S$ transition of the cell cycle. They bind to specific sites in the promoters of genes that are required for entry into the S phase (Polager et al., 2002). Interestingly, the E2F-1 promoter itself contains E2F-binding sites (Johnson et al., 1994). In quiescent cells, E2F factors are rendered inactive by binding to $\mathrm{pRB}$ and related proteins. In addition to this sequestration, the E2F-pRB complexes act as transcription repressors on the E2F sites (Sellers et al., 1995). On the other hand, in transformed cells the $\mathrm{pRB}$ pathway is commonly altered, and therefore E2F activity is constantly elevated. Identification of the E2F-1 promoter (Hsiao et al., 1994; Neuman et al., 1994) offered the possibility of using it for transcriptional targeting of tumors (Parr et al., 1997). It is important to mention that viral protein E1A can disrupt E2F-pRB complexes and therefore ac- tivate the E2F-1 promoter (Flint and Shenk, 1997). This means that the alteration in the $\mathrm{pRB}$ pathway might not be a requirement for replication of AdEHE2F if the promoter controlling the E1A region is already activated. However, in most normal tissues, the absence of ERs and the low levels of HIF and E2F activity should keep both E1A and E4 transcription units inactive (Fig. 1). In summary, we found both AdEHT2 and AdEHE2F viruses to be fully active in $\mathrm{ER}^{+}$cancer cells, or in cells growing under hypoxic conditions, in good correlation with the expression of the E1A region. Regarding the E4 region, we were unable to demonstrate restriction of AdEHT2 viral replication in telomerase-negative cells. On the other hand, we observed attenuation of AdEHE2F replication in normal quiescent cells, which suggests that the E2F-1 promoter retains its specificity in the context of the adenovirus genome.

\section{MATERIALS AND METHODS}

\section{Cell lines}

MCF7 (ATCC HTB 22) and BT-474 (ATTC HTB 20) are $\mathrm{ER}^{+}$human breast cancer cell lines. SK-BR-3 (ATCC HTB 30) is an $\mathrm{ER}^{-}$human breast cancer cell line. Cells were maintained in RPMI medium (BioWhittaker, Walkersville, MD) supplemented with $10 \%$ fetal bovine serum (FBS) (HyClone, Logan, UT). For MCF7 and BT-474, insulin (10 $\mu \mathrm{g} / \mathrm{ml}$; GIBCO-BRL, Grand Island, NY) was added. HeLa (ATCC CCL 2) is an ER ${ }^{-}$ human cervical cancer cell line, and it was maintained in Dulbecco's modified Eagle's medium (DMEM; GIBCO-BRL) supplemented with 10\% FBS. IMR-90 (ATCC CCL 186) and BJ (ATCC CRL-2522) are human primary fibroblasts from lung and skin, respectively. They were maintained in Eagle's minimal essential medium (EMEM; BioWhittaker), supplemented with $10 \%$ FBS, $0.1 \mathrm{~m} M$ nonessential amino acids, and sodium

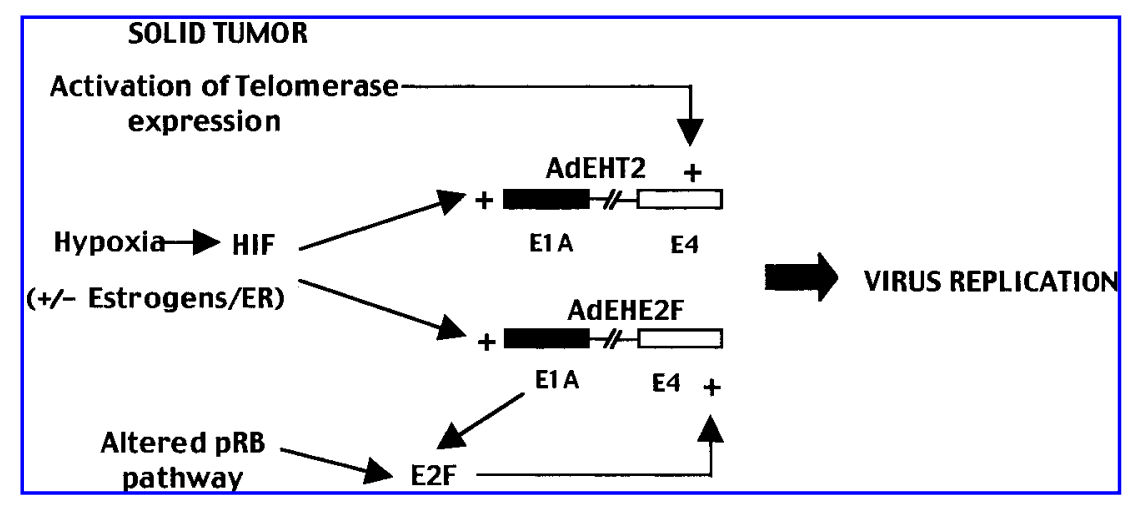

FIG. 1. Proposed mechanism for the preferential replication of AdEHT2 and AdEHE2F in solid tumors. On the left, some general characteristics of solid tumors are listed, and their influence on the replication of viruses is indicated with arrows. The E1A and E4 transcription units of adenovirus are represented as solid and open boxes, respectively. A hypoxic environment and the expression of estrogen receptors in the cells can independently activate the E1A unit of both viruses. The E4 unit of AdEHT2 is supposed to be activated in cells that express telomerase, and therefore it might attenuate the replication of the virus in telomerase-negative cells (see text). The E4 unit of AdEHE2F should be activated in cells that show alterations in the pRB pathway, because the levels of free E2F transcription factors are elevated in these cells. Because the viral E1A protein can produce the same effect, hypoxia and estrogens in $\mathrm{ER}^{+}$cells can indirectly activate the E4 unit of AdEHE2F. The expression of E1A and E4 units would allow adenoviral replication, destruction of the cells, and propagation of the infection within the tumor. 
bicarbonate (1.5 g/liter) (GIBCO-BRL). NHFib cells are also human skin fibroblasts, and were maintained in DMEM supplemented with $10 \%$ FBS. Human dermal microvascular endothelial cells (HDMECs) were maintained in EBM-2 medium supplemented with EGM-2-MV (endothelial microvascular cell growth medium 2) additives (Clonetics, Walkersville, MD). NHK cells are normal human keratinocytes from skin. They were maintained in medium 154CF supplemented with HKGS (Cascade Biologics, Portland, OR). When the experiment required depletion of estrogens, IMEM without phenol red was used (GIBCO-BRL), supplemented with $2.5 \%$ charcoal-dextran-stripped serum (HyClone). Estradiol (17 $\beta$-estradiol) and 4$\mathrm{OH}$-tamoxifen were purchased from Sigma (St. Louis, MO). A549 (ATCC CCL 185) is a human lung cancer cell line. It was maintained in Ham's F12 (BioWhittaker) supplemented with 10\% FBS. 293E4pIX cells (Microbix, Toronto, ON, Canada) are a 293 cell line transformed with the adenovirus type $5 \mathrm{E} 4$ transcription unit driven by the dexamethasone-inducible mouse mammary tumor virus (MMTV) promoter, and the protein IX unit driven by the $\mathrm{ZnCl}_{2}$-inducible metallothionein promoter. It was maintained in EMEM supplemented with $10 \%$ heat-inactivated FBS. The expression of the E4 unit was induced by adding $1 \mu M$ dexamethasone (Gensia, Irvine, $\mathrm{CA})$ to the culture medium. All culture media were supplemented with penicillin $(100 \mathrm{U} / \mathrm{ml})$, streptomycin $(100 \mathrm{U} / \mathrm{ml})$, and amphotericin B (Fungizone, $0.25 \mu \mathrm{g} / \mathrm{ml}$; BioWhittaker).

\section{Construction and characterization of reporter plasmids}

The pB5XEH3 plasmid was constructed as follows. A cassette containing five copies of the ERE (GGTCACAGTGACC) plus a TATA box were subcloned into the polycloning site of the pGL2-Basic luciferase reporter plasmid (Promega, Madison, WI). Three copies of the HRE consensus element of the mouse phosphoglycerate kinase 1 (PGK-1) 5' enhancer (TGTCACGTCCTGCACGAC) were then subcloned upstream of the ERE sequences, using the $S m a I$ site. To verify the response to estrogens, the plasmid was transfected into MCF7 cells, using the FuGENE 6 reagent, as described by the manufacturer (Roche, Indianapolis, IN). The cells (typically $7.5 \times 10^{4} /$ well in a 12-well plate) were incubated for $8 \mathrm{hr}$ in estrogen-free medium and then transfected with $0.5 \mu \mathrm{g}$ of the reporter plasmid and $0.1 \mu \mathrm{g}$ of the plasmid pRLTK (Promega) in order to quantify the efficiency of transfection. Six hours later, the transfection medium was removed and new medium was added containing the indicated treatments. After 14-18 hr, cells were lysed and analyzed for luciferase activity, using the dual luciferase reporter assay system (Promega) as indicated by the manufacturer. The specific luciferase activity measured in a luminometer is presented as (firefly/Renilla) $\times 1000$ luciferase units.

\section{Construction of AdEHT2 and AdEHE2F}

Using the plasmid pShutAd (Hernandez-Alcoceba et al., 2000), we used standard molecular biology methods to produce a plasmid containing the E1A and E4 promoters flanked by unique restriction sites. The E1A promoter region (bp 341 to 499) was flanked by BstBI sites. The E4 promoter region (bp 35619 to 35818 ) was flanked by I-CeuI and $S w a I$ sites, as shown in Fig. 2A. An insulator sequence (bovine growth hormone transcription stop signal) was subcloned upstream of the E1A promoter. The insulator was obtained from the pcDNA3 plasmid (Invitrogen, Carlsbad, CA) by digestion with PvuII and NotI (Vassaux et al., 1999). The core hTERT promoter (bp -208 to $+76)$ and the E2F-1 promoter (bp -218 to +51$)$ were amplified from genomic DNA with the Advantage-GC genomic PCR kit (Clontech, Palo Alto, CA). The primers used were 5'-TACTGTAACTATAACGGTCCTAAGGTAGCGACCAGTGGATTCGCGGGCACAG-3' and 5'-TAAGTATTTAAATCGCGGGGGTGGCCGGGGCCAGGGCTTC-3' for the hTERT promoter, and 5' -TACTGTAACTATAACGGTCCTAAGGTAGCGTGGTACCATCCGGACAAAGCC-3' and 5'-TAAGTATTTAAATGGCGAGGGCTCGATCCCGC-3 ' for the E2F1 promoter. The plasmids containing the modified adenovirus genome were named pSEHT2 and pSEHE2F, respectively. For the production of viral particles, these plasmids were digested with PacI, phenol-chloroform extracted and ethanol precipitated, and then transfected into 293E4pIX cells by the calcium phosphate method. The cells were treated with $1 \mu M$ dexamethasone until cytopathic effect (CPE) was observed. Individual plaques were isolated as described (Hernandez-Alcoceba $t$ $a l ., 2000)$. Modifications in the E1A and E4 promoter regions were verified by polymerase chain reaction (PCR) using specific primers. The viruses were amplified in A549 cells, purified on $\mathrm{CsCl}$ gradients, and desalted in G-50 Sephadex columns. Titration was done according to the plaque-forming assay method. The titer was $1.1 \times 10^{7}$ and $0.7 \times 10^{7} \mathrm{PFU} / \mu \mathrm{l}$ for AdEHE2F and AdEHT2, respectively.

\section{Analysis of transcriptional activation of E1A and E4 units}

To analyze the responsiveness of the ERE/HRE promoter in the context of the adenoviral genome, we performed Northern blot assays of cells infected with AdEHT2 and AdEHE2F. Wild-type adenovirus type 5 (AdWT) was used as a control. Cells $\left(5 \times 10^{6}\right.$ cells/100-mm plate $)$ were pretreated for 10 or $14 \mathrm{hr}$ under the indicated conditions of estrogens and/or hypoxia. Infection was performed for $1 \mathrm{hr}$ in $3 \mathrm{ml}$ of culture medium with a multiplicity of infection (MOI) of $20 \mathrm{PFU} / c e l l$. The infection medium was then removed and the cells were incubated for $10 \mathrm{hr}$ under the same conditions. Total RNA was extracted with TRIzol reagent (GIBCO-BRL), and $30 \mu \mathrm{g}$ of RNA was formaldehyde-formamide denatured, fractionated in a $1.2 \%$ agarose gel, and transferred to a nylon membrane (Hybond-N+; Amersham, Buckinghamshire, UK). The E1A probe consisted of the 998-bp SspI-XbaI fragment from the adenoviral genome (nucleotides 341 to 1339), and the E4 probe was the 800-bp SspI-AsnI fragment (nucleotides 34634 to 35419 ). They were radiolabeled with a random primed DNA labeling kit (Roche). The membrane was prehybridized for $2 \mathrm{hr}$ at $68^{\circ} \mathrm{C}$ in ExpressHyb hybridization solution (Clontech) in the presence of salmon sperm DNA $(1 \mathrm{mg} / \mathrm{ml})$ and tRNA $(1 \mathrm{mg} / \mathrm{ml})$. Hybridization was at $68^{\circ} \mathrm{C}$ for $1 \mathrm{hr}$ with $2 \times 10^{6} \mathrm{cpm} / \mathrm{ml}$ of the probe. The membrane was then washed with $2 \times \mathrm{SSC}, 0.1 \%$ sodium dodecyl sulfate (SDS) at room temperature for $20 \mathrm{~min}$, and twice with $0.1 \times \mathrm{SSC}, 0.1 \% \mathrm{SDS}$ at $50^{\circ} \mathrm{C}(1 \times \mathrm{SSC}$ is 0.15 $M \mathrm{NaCl}$ and $15 \mathrm{~m} M$ sodium citrate, $\mathrm{pH} 7.0$ ). Finally, it was autoradiographed. To confirm homogeneousRNA loading and hy- 


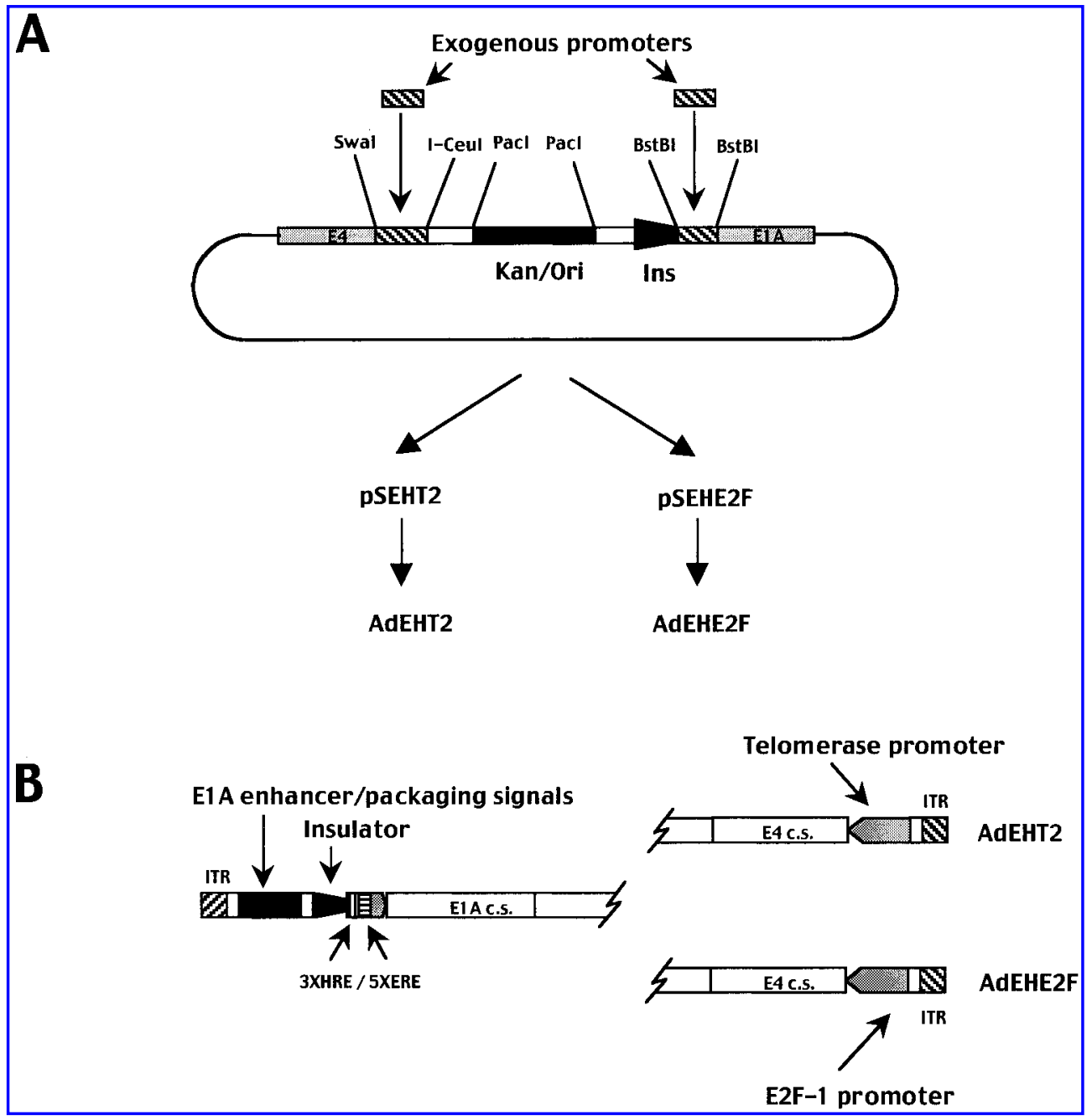

FIG. 2. Construction of AdEHT2 and AdEHE2F. (A) Method for the production of adenoviruses with modifications in the E1A and E4 promoters. These regions were flanked by unique restriction sites (BstBI for E1A and SwaI/I-CeuI for E4) in a plasmid that contains the entire adenovirus type 5 genome. After subcloning the exogenous promoters, the plasmids obtained (pSEHT2 and pSEHE2F in this case) are digested with $\mathrm{PacI}$ in order to liberate the viral genome, and they are transfected in permissive cells to generate the CRADs AdEHT2 and AdEHE2F, respectively. Kan, Kanamycin resistance; Ori, origin of replication for $E$. coli; Ins, insulator sequence. (B) Schematic representation of the modifications introduced in the viral genome. An insulator sequence was placed between the overlapping E1A enhancer/packaging signals and the E1A promoter. The wild-type E1A promoter was substituted with an artificial minimal promoter containing three hypoxia responsive elements (HREs) and five estrogen response elements (EREs). The E4 promoter was substituted with the hTERT and E2F-1 promoters in AdEHT2 and AdEHE2F, respectively. ITR, Inverted terminal repeats; c.s., coding sequence.

bridization, we hybridized the same membranes with a human $\beta$-actin probe.

\section{Cytopathic effect and viability of cells}

After infection of cells with the different viruses, the appearance of cytopathic effect (rounding and detachment) was monitored and cells were photographed with a digital camera (Pixera, Los Gatos, CA), typically 9 days after infection (data not shown). To quantify the viability of cells, the MTT assay was used (Sigma). At the time of analysis, cells were washed with $1 \mathrm{ml}$ of phosphate-buffered saline (PBS) and $300 \mu \mathrm{l}$ of a solution containing thiazolyl blue (MTT) solution $(0.8 \mathrm{mg} / \mathrm{ml})$ was added to the cells. Five hours later, $300 \mu \mathrm{l}$ of solubilization solution $(20 \%$ [w/v] SDS in $50 \%$ [v/v] $N, N$-dimethylformamide) were added, and $12 \mathrm{hr}$ later the absorbance at $600 \mathrm{~nm}$ was read in a spectrophotometer. The significance of the differences observed was analyzed by $t$ test.

\section{In vivo assays in nude mice}

The antitumor effect of AdEHT2 and AdEHE2F was tested in human tumor xenografts implanted in 5- to 7-week-old Hsd $n u / n u$ mice (Harlan, Indianapolis, IN). Estradiol pellets $(0.72$ mg of $17 \beta$-estradiol, 60-day release; Innovative Research of America, Sarasota, FL) were implanted subcutaneously in the 
mice. Two days later, $15 \times 10^{6} \mathrm{BT}-474$ cells were resuspended in serum-free RPMI plus $80 \%$ Matrigel (Collaborative Biomedical Products, Bedford, MA) and injected subcutaneously into the second left breast. When tumors reached an average volume of approximately $200 \mathrm{~mm}^{3}$, viruses were diluted to $5 \times$ $10^{8} \mathrm{PFU}$ in $100 \mu \mathrm{l}$ of PBS and injected intratumorally. Tumor volume was measured weekly and calculated according to the equation $\left(D \times d^{2}\right) / 2$, where $D$ and $d$ are the major and minor diameters, respectively. The significance of the differences observed was analyzed by $t$ test.

The toxicity assays were performed in Hsd $n u /+$ mice by intravenous injection of $100-\mu l$ virus solutions in PBS via the retro-orbital plexus. Mice were monitored daily for signs of mortality and morbidity. Two days after viral injection, blood samples were collected and levels of the hepatic enzyme alanine aminotransferase (ALT) were analyzed in order to assess liver toxicity.

\section{RESULTS}

\section{Construction of AdEHT2 and AdEHE2F}

To test different combinations of promoters in the E1A and E4 transcription units of adenovirus, we constructed a plasmid containing the adenovirus type 5 genome with these regions flanked by unique restriction sites (Fig. 2A), as suggested by Mizuguchi and Kay (1998). In the E4 region, we subcloned the hTERT promoter (virus AdEHT2) or the E2F-1 promoter (virus AdEHE2F), as indicated in Fig. 2B. These promoters have already been described by other groups (Hsiao et al., 1994; Neuman et al., 1994; Horikawa et al., 1999; Takakura et al., 1999;
Wick et al., 1999). The control of the E1A region is crucial for the regulation of CRADs. The wild-type virus contains a strong enhancer for E1A that overlaps with the packaging signal. To prevent any possible interference with the function of the exogenous promoter used in this area, we introduced an insulator sequence (bovine growth hormone transcription stop signal) between this enhancer and the location of the E1A promoter. In an effort to minimize the basal activity of the promoter, we constructed and characterized a new minimal promoter containing three HREs and five EREs plus a TATA box. A luciferase reporter was used to test its activation by estrogens and hypoxia (Fig. 3). The $\mathrm{ER}^{+}$human breast cancer cell line MCF7 was transiently transfected with this plasmid and the cells were exposed to estrogens ( $2.5 \mathrm{n} M 17 \beta$-estradiol), hypoxia $\left(1 \% \mathrm{O}_{2}\right)$, or both stimuli together. The result shows that this promoter has low basal activity in the absence of estrogens (Fig. 3A). As described previously for a similar promoter, both estrogens and hypoxia stimulated transcription, which means that the HRE and ERE sites can work independently. However, in the case of this artificial promoter the response to estrogens (25-fold over the untreated cells) was lower than that obtained with hypoxia (80fold). The addition of the estrogenic competitive inhibitor 4-OHtamoxifen partially blocked the response to estrogens, indicating that the induction is specific (Fig. 3A). In ER- HeLa cells, no elevation of the luciferase activity was observed, whereas hypoxia was still able to stimulate transcription (Fig. 3B). In summary, the ERE/HRE minimal promoter combined low basal activity with good inducibility. Its reduced size and the lack of potentially undesirable response elements make it a good candidate for substitution of adenoviral regulatory sequences. We then introduced it in the adenovirus genome, replacing the wildtype E1A promoter in both AdEHT2 and AdEHE2F (Fig. 2B).

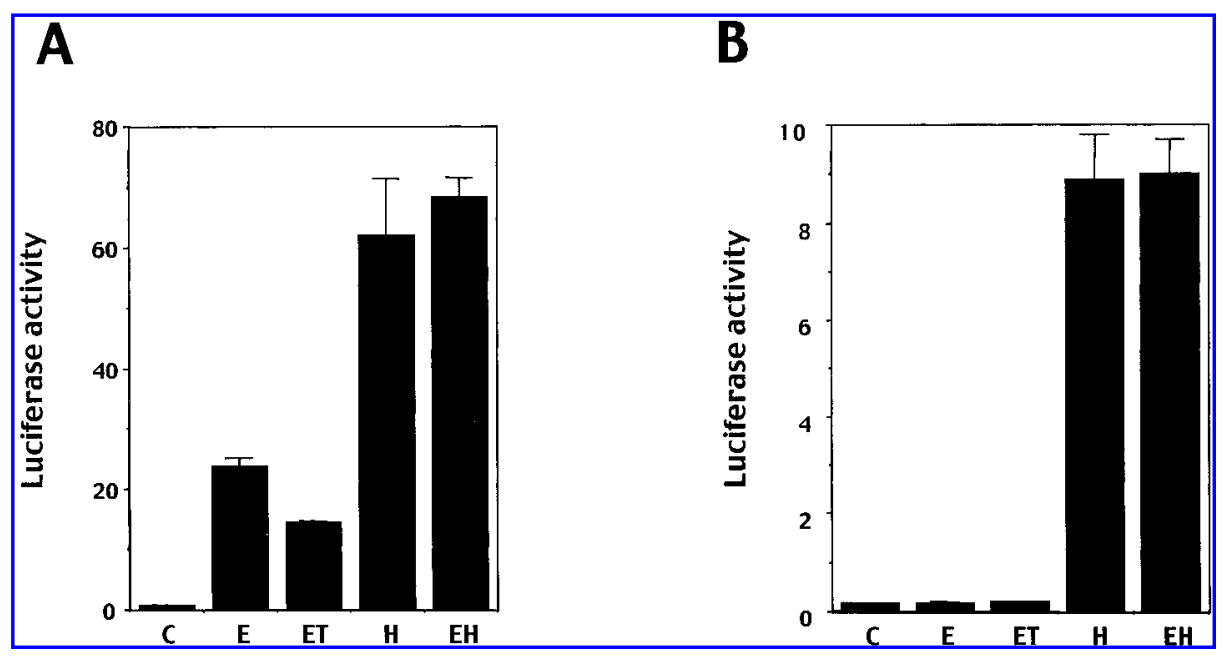

FIG. 3. Characterization of the ERE/HRE minimal promoter. The pB5XEH3 luciferase reporter plasmid containing this promoter was transfected into MCF7 cells (A) or HeLa cells (B) that had been estrogen deprived for 8 hr. The constitutive Renilla luciferase reporter pRLTK was cotransfected in order to control the efficiency of transfection. Six hours later, the transfection medium was removed and new medium containing the indicated treatments was added. After 16 hr, the cells were lysed and analyzed for luciferase activity. The columns represent the equation (firefly/Renilla) luciferase units $\times 10^{3}$. Note that the $y$ axis range is different in each panel. C, Untreated; E, $2.5 \mathrm{n} M 17 \beta$-estradiol; ET, $2.5 \mathrm{n} M$ 17 $\beta$-estradiol plus $2.5 \mu M$ 4-OH-tamoxifen; $\mathrm{H}$, hypoxia $\left(1 \% \mathrm{O}_{2}\right) ; \mathrm{EH}, 2.5 \mathrm{n} M 17 \beta$-estradiol plus hypoxia. The experiment was repeated five times for MCF7 cells and two times for HeLa cells, with similar results. 
The viral particles were produced by transfection of the respective plasmids, as described in Materials and Methods.

\section{Transcriptional control of the E1A and E4 regions}

Once the AdEHT2 and AdEHE2F viruses were produced, we investigated whether the exogenous promoters were able to control the expression of E1A and E4 in the context of the adenovirus genome. We used MCF7 as an example of an $\mathrm{ER}^{+}$ cell line and HeLa as an example of an ER ${ }^{-}$cell line. IMR-90 cells are nontransformed human primary fibroblasts from lung that suffer senescence after a series of passages in culture. We verified by reverse transcriptase (RT)-PCR that MCF-7 and HeLa cells express telomerase, whereas IMR-90 cells are negative (data not shown), as described in the literature (Meyerson et al., 1997; Majumdar et al., 2001). Cells were infected for 10 hr with an MOI of $20 \mathrm{PFU} / \mathrm{cell}$ of either AdEHT2, AdEHE2F, or AdWT as a control. Cells were maintained in RPMI medium supplemented with $2 \%$ FBS and $2 \mathrm{n} M 17 \beta$-estradiol, with or without hypoxia $\left(1 \% \mathrm{O}_{2}\right)$. In addition, a set of MCF7 cells was incubated in the absence of estrogens. Total RNA was extracted and expression of the E1A and E4 transcription units was analyzed by Northern blot using specific probes, as shown in Fig. 4. There is a tight regulation of the E1A region in both AdEHT2 and AdEHE2F. In all the cell lines tested, hypoxia induced strong expression of E1A. Importantly, the expression was un- detectable in the $\mathrm{ER}^{-}$cell line HeLa under normoxic conditions. In MCF7 cells basal expression was low, estrogens caused activation, and the best response was obtained by hypoxia and estrogens together. These data indicate that the minimal ERE/HRE promoter maintains its properties of low basal activity and high inducibility in the context of the adenoviral genome. The use of an insulator sequence might contribute to the tight regulation of the E1A region in these viruses. On occasion, cells infected with AdWT showed a slight increase in E1A expression in response to hypoxia, as is the case for HeLa in this assay. In fact, analysis of the left arm of the adenovirus genome reveals some HRE-like sequences. The significance of this finding is unclear, because the ability of the wild-type virus to replicate was not significantly increased by hypoxia (see below). Probably the increase in E1A expression above a certain threshold is irrelevant for its function. In contrast with the high levels of E1A obtained in cells infected with the recombinant adenovirus, the expression of the E4 region in both viruses was relatively low when compared with the wild-type virus. This is especially true for IMR-90 cells, which lack expression of telomerase. However, it is not clear that this is due to specific regulation of the hTERT or E2F-1 promoter. As can be seen in HeLa cells infected for $10 \mathrm{hr}$ with AdEHT2 and AdEHE2F, the expression of E4 is low unless the cells are maintained under hypoxic conditions. This suggests that the signals controlling expression of telomerase or the basal levels of E2F in these

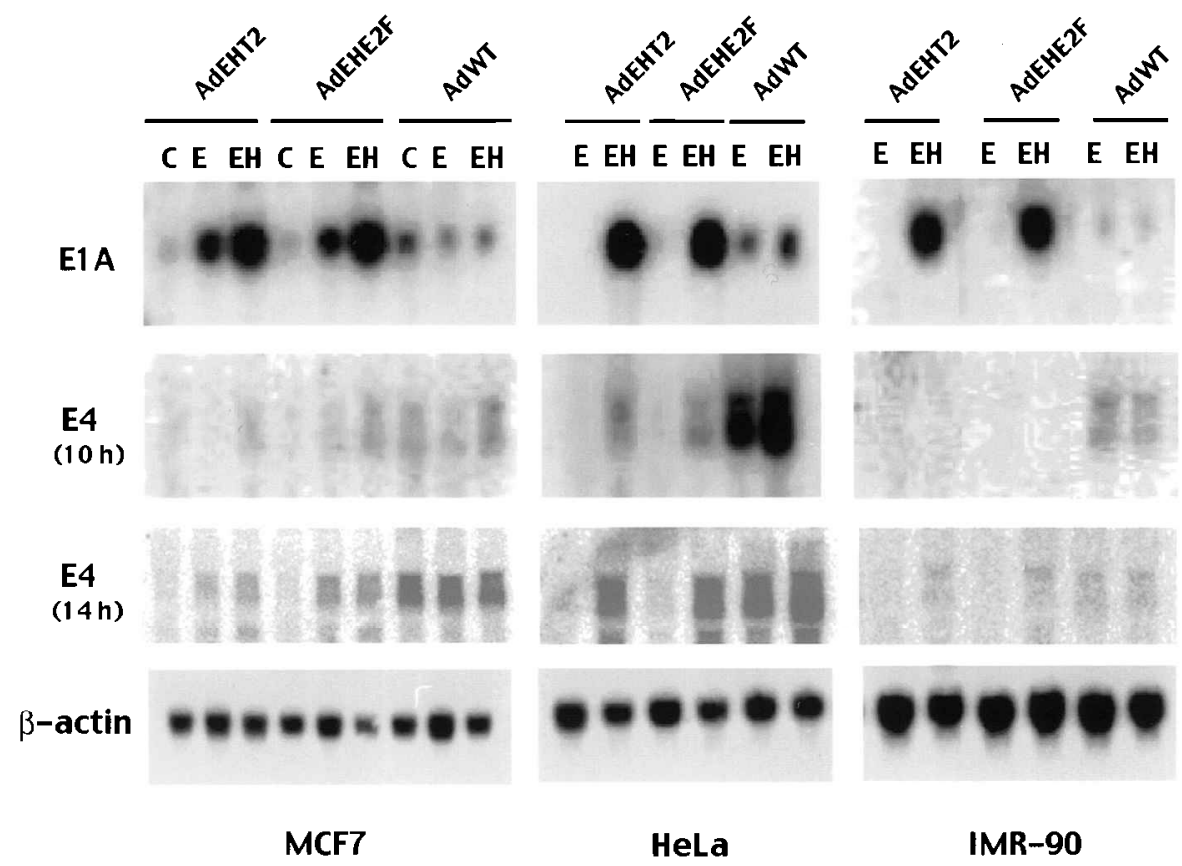

FIG. 4. Transcriptional control of the E1A and E4 units. MCF7, HeLa, and IMR-90 cells were pretreated for $10 \mathrm{hr}$ with $2 \mathrm{n} M$ $17 \beta$-estradiol (E) or $2 \mathrm{n} M 17 \beta$-estradiol plus hypoxia (EH). In addition, one set of MCF7 cells was maintained in estrogen-depleted medium (C). Cells were then infected with an MOI of 20 PFU/cell of AdEHT2, AdEHE2F, or AdWT, under the same treatment conditions. Ten or $14 \mathrm{hr}$ after infection, total RNA was extracted. Northern blot analysis was performed with radioactive probes specific for the E1A region, E4 region, or the constitutively expressed $\beta$-actin gene as a control. The intensity of the signal should not be compared between different cells because in this short period of time, it reflects mostly the sensitivity of the cells to adenovirus infection (which is highest in HeLa cells and lowest in IMR-90 cells, as can be deduced from the intensity of the signal obtained in AdWT-infected cells). The times of exposure of the autoradiograms are different for each blot. The experiment was repeated three times with similar results. 
transformed cells are by themselves unable to stimulate E4. However, under hypoxic conditions the levels of E1A are high and this appears to cooperate in the activation of the E4 promoter. In the case of AdEHE2F, this may be a consequence of the sequestration of pRB by E1A. In AdEHT2, a less specific mechanism could be taking place, because E1A is known as a ubiquitous activator of transcription in many promoters (Flint and Shenk, 1997), and that may be happening to the hTERT promoter as well. To evaluate the regulation of the E4 region in more detail, we repeated the Northern blot assays $14 \mathrm{hr}$ after infection, as indicated in Fig. 4. At this time, the influence of E1A is more evident. In fact, the expression of E4 in MCF7 and HeLa cells infected with the CRADs clearly responds to the same stimuli (expression of ERs and hypoxia). Although E4 is still low in IMR-90 cells, a slight increase can be observed under hypoxic conditions, especially in the case of AdEHE2F. In summary, the activity of the E4 unit driven by the hTERT and E2F-1 promoters is attenuated in normal cells, but it can be influenced by the levels of E1A.

\section{Modulation of the cytotoxicity of AdEHT2 and AdEHE2F by hypoxia}

Hypoxia is a strong activator of the E1A region for both AdEHT2 and AdEHE2F, and this also affects expression of the E4 region indirectly. We then examined the consequences of this regulation on the ability of these viruses to replicate and kill cells in culture. We compared the $\mathrm{ER}^{+}$cell lines MCF7 and BT-474, and the ER ${ }^{-}$cell lines HeLa and SK-BR-3. Cells were infected with AdEHT2, AdEHE2F, or AdWT at an MOI of 10
PFU/cell and viability was quantified 9 days after infection, using the MTT assay (Fig. 5). We chose an MOI that caused no $\mathrm{CPE}$ in the first 3 days postinfection even with the wild-type virus, to make sure that any effect that appears later on is due to virus replication. All the cells were incubated in the presence of $17 \beta$-estradiol; some of them under normoxic and some under hypoxic conditions. In good correlation with the expression of E1A, both recombinant adenoviruses caused extensive death of MCF7 cells in the presence of estrogens (90\% decrease in viability), with or without hypoxia. The same was true for the other $\mathrm{ER}^{+}$cell line BT-474, with virtually complete eradication of cells at the end of the experiment. On the other hand, HeLa cells were not significantly affected under normoxic conditions, which suggests that the expression of ER is necessary for activation of the viruses in the absence of hypoxia. However, lowering the oxygen tension to $1 \%$ caused significant activation of the capacity of the CRADs to kill these cells, with $80 \%$ reduction in viability observed with AdEHE2F. In the case of SK-BR-3, hypoxia stimulates the cytotoxicity of the recombinant adenoviruses, but the attenuation under normoxic conditions is only partial, especially for AdEHE2F. Interestingly, this cell line overexpresses the Her2/neu oncogene (Moulder et al., 2001), which can cause increased levels of HIF in the absence of hypoxia (Laughner et al., 2001). Note that the ability of AdWT to kill cells was not affected by hypoxia. In summary, hypoxia induced a significant increase in cytotoxicity only for AdEHT2 and AdEHE2F, and the expression of ERs in the cells had a permissive role for these viruses. Finally, we performed a dose-response analysis and calculated the MOI of virus necessary to kill $50 \%$ of the cells in order to estimate the extent of

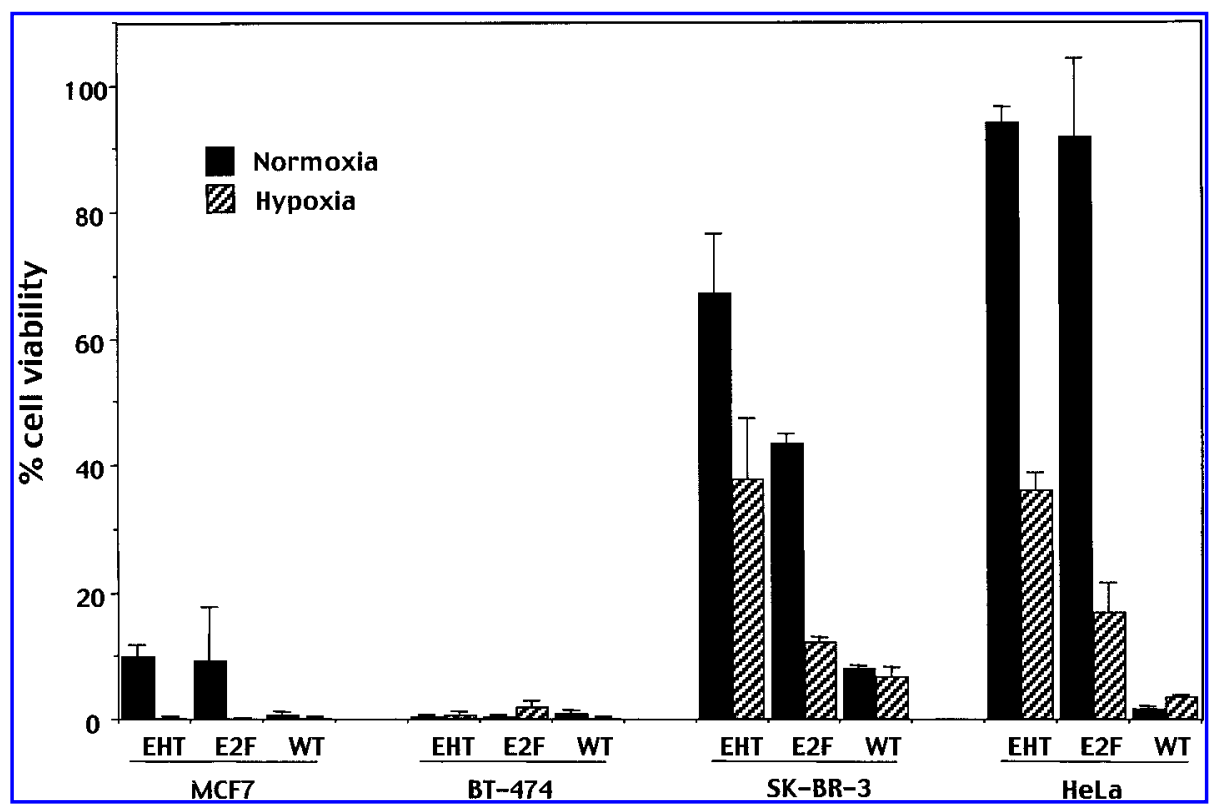

FIG. 5. Viability of different human cancer cell lines infected with AdEHT2 and AdEHE2F. The ER ${ }^{+}$cell lines MCF7 and BT-474, and the ER ${ }^{-}$cell lines HeLa and SK-BR-3, were infected with AdEHT2 (EHT), AdEHE2F (E2F), or AdWT (WT) at an MOI of $10 \mathrm{PFU} / \mathrm{cell}$ in the presence of $2 \mathrm{n} M 17 \beta$-estradiol. Cells were maintained under normoxic conditions (solid columns) or hypoxic conditions (hatched columns) for 9 days, and viability was analyzed by the MTT assay. The columns represent the percentage of surviving cells, compared with uninfected cells growing under the same conditions. The experiment was repeated five times with similar results. 
Table 1. Modulation of Cytotoxicity of AdEHT2 AND AdEHE2F B y Hypoxia ${ }^{\text {a }}$

\begin{tabular}{lrrlllll}
\hline & \multicolumn{2}{c}{ AdEHT2 } & \multicolumn{2}{c}{ AdEHE2F } & \multicolumn{2}{c}{ AdWT } \\
\hline & $N$ & $H$ & $N$ & $H$ & \multicolumn{1}{c}{$N$} & $H$ \\
\hline BT-474 & 2 & 0.5 & 0.4 & 0.2 & 0.05 & 0.07 \\
HeLa & $>100$ & 19 & 60 & 6 & 1 & 1 \\
\hline
\end{tabular}

${ }^{\text {aBT }}-474$ and HeLa cells were infected with the indicated viruses at different MOIs in the presence of $2 \mathrm{n} M 17 \beta$-estradiol, under normoxic $(\mathrm{N})$ or hypoxic $(\mathrm{H})$ conditions. Ten days after infection, the viability of the cells was evaluated by the MTT assay. Shown are the MOIs that caused $50 \%$ loss of viability compared with uninfected cells.

regulation by hypoxia. In HeLa cells hypoxia can stimulate at least 10-fold the ability of CRADs to eliminate these cells (Table 1). In BT-474 cells, the maximum cytotoxicity effect was always achieved when both estrogens and hypoxia were present, but the expression of ERs allowed nearly full activity of the viruses. Overall, AdEHE2F was 3-fold more cytotoxic than AdEHT2, but it was still attenuated about 5-fold when compared with the wild-type adenovirus, whose cytotoxicity was not affected by hypoxia. In summary, these results indicate that the expression of ERs in the cells, or the existence of a hypoxic environment, are key factors that control the proliferation and cytotoxicity of the new CRADs.

\section{Evaluation of the hTERT and E2F-1 promoters in the E4 region of adenovirus}

The purpose of placing the E4 region of adenovirus under the control of the hTERT promoter was to confine the replication of adenovirus only to cells that express telomerase. Northern blot assays showed that the activity of the E4 region of
AdEHT2 seemed to be attenuated in IMR-90 primary cells, which do not express this enzyme (Fig. 4). However, the activation of the promoter in HeLa or MCF7 cells was also low, and it was apparent only when E1A expression was also activated by hypoxia. Despite the low levels of E4 in MCF7 cells under normoxic conditions, AdEHT2 was still able to replicate and kill these cells. The consequences of this situation in terms of virus replication and cytotoxicity were evaluated in a viability assay using telomerase-negative IMR-90 cells. As shown in Fig. 6A, when these cells were infected under hypoxic conditions, AdEHT2 was not attenuated. In fact, it showed effects similar to those of the wild-type virus, suggesting that the influence of E1A expression activated by hypoxia is sufficient to allow replication of the virus. When the same experiment was repeated with AdEHE2F, a more pronounced reduction of cell viability was observed with hypoxia treatment (Fig. 6B). In this case the result is not surprising if we consider that in some situations, E1A can activate the E2F-1 promoter by blocking the pRB pathway (Flint and Shenk, 1997).

To evaluate the ability of the E2F-1 promoter to attenuate the replication of adenovirus in quiescent cells, we compared the viability of IMR-90 cells infected with AdEHE2F in serumfree medium versus medium that contains $2 \%$ FBS. Unlike most cancer cell lines, these primary cells do not express E2F-1 and other proliferation-related transcription factors when they are maintained in serum-free medium, but serum can reactivate their expression (Good et al., 1996). Figure 7A shows that, as expected, AdEHE2F was attenuated in quiescent cells. This effect was not a general characteristic of adenovirus, because it was not observed with AdWT. Actually, the cells were slightly more sensitive when infected with this virus in serum-free medium (Fig. 7B). In addition, the attenuation did not take place in the breast cancer cell line MCF7 (Fig. 7C). These results suggest that the E2F-1 promoter controlling the E4 region can help to diminish the replication of adenovirus in normal somatic

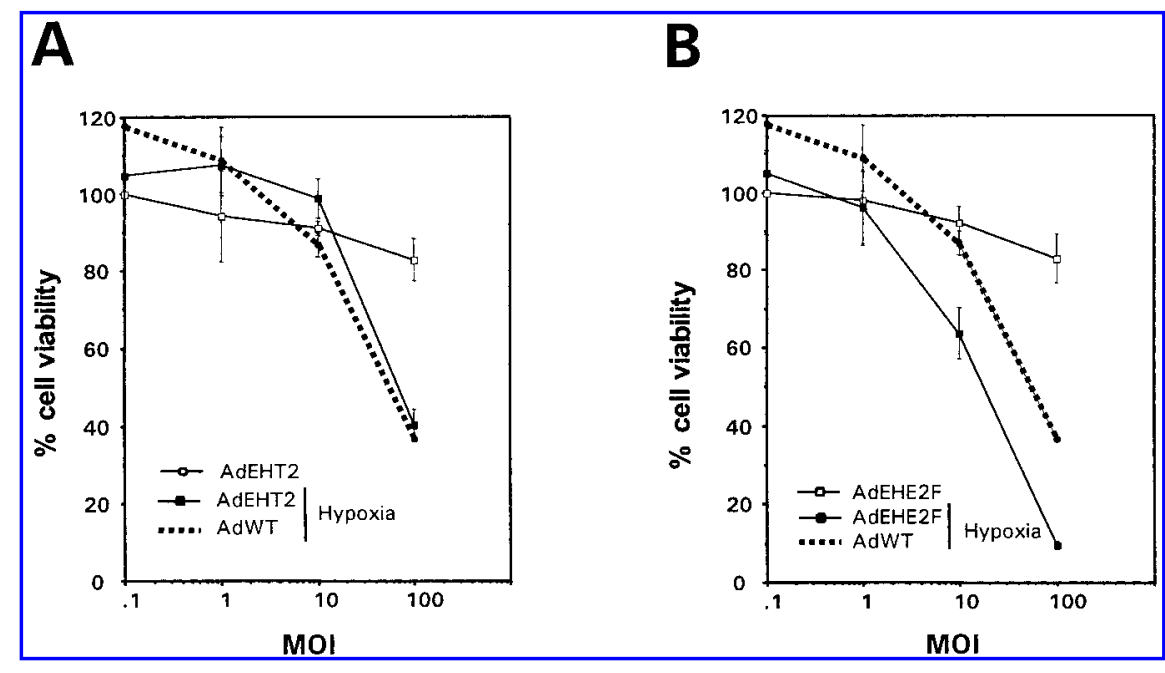

FIG. 6. Viability of IMR-90 cells infected with AdEHT2 and AdEHE2F. Telomerase-negative IMR-90 cells were infected with AdEHT2 (A) or AdEHE2F (B) at different MOIs in the presence of $2 \mathrm{n} M 17 \beta$-estradiol, under normoxic (open squares) or hypoxic (solid squares) conditions. As a control, cells were infected with AdWT under hypoxic conditions (discontinuous line). The viability of the cells was analyzed 10 days after infection, using the MTT assay. The percentage of viable cells is presented on the $y$ axis and the MOI in logarithmic scale is presented on the $x$ axis. The experiment was repeated three times with similar results. 


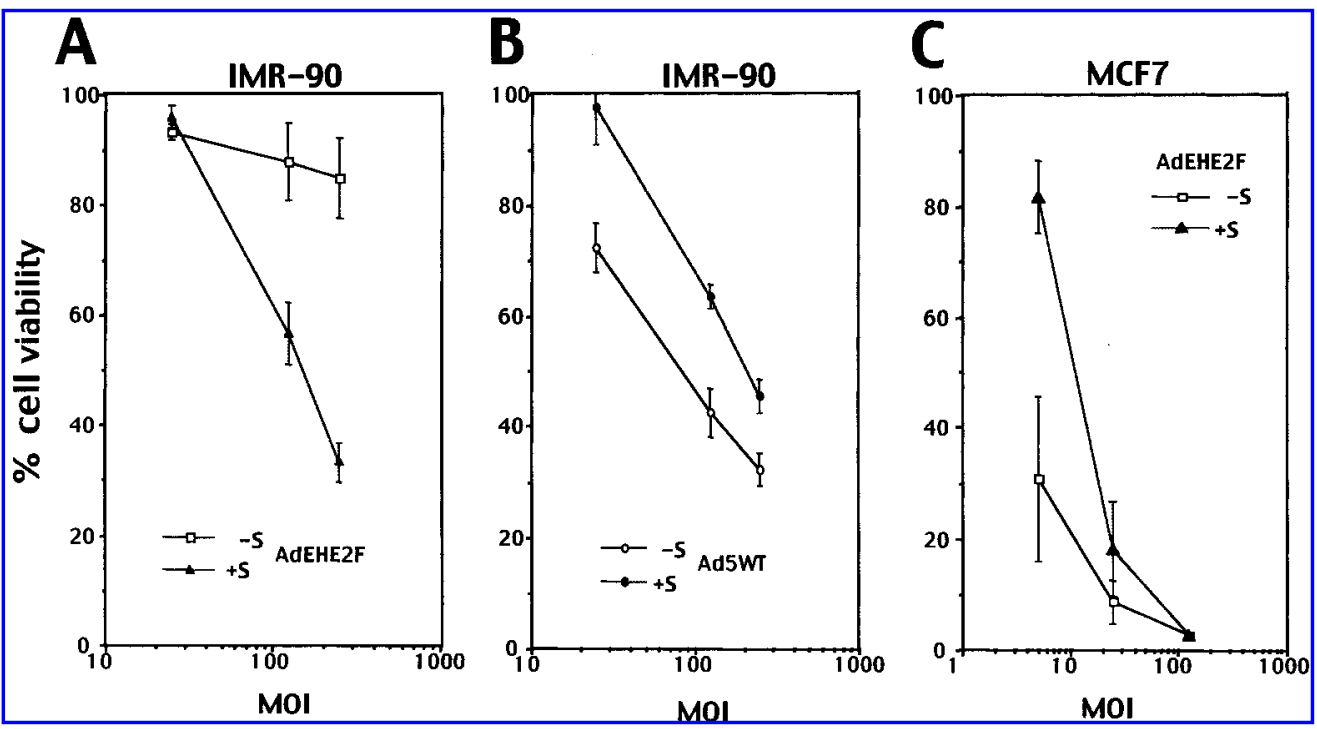

FIG. 7. Cytotoxicity of AdEHE2F in quiescent cells. (A) IMR-90 cells were infected with different MOIs of AdEHE2F in the presence of $2 \mathrm{n} M 17 \beta$-estradiol. The cells were maintained in serum-free medium (open squares), or in the usual infection medium containing $2 \%$ FBS (solid triangles). The viability was analyzed 8 days after infection, using the MTT assay. The percentage of viable cells is presented on the $y$ axis and the MOI in logarithmic scale is presented on the $x$ axis. The same experiment was performed with the AdWT virus and IMR-90 cells (B), and with AdEHE2F virus and MCF7 cells (C). Note that the MOIs used are lower in the case of MCF7 cells. For this assay, we infected a higher initial number of IMR-90 cells than in previous viability assays $\left(2 \times 10^{4}\right.$ versus $\left.5 \times 10^{3}\right)$, because these cells do not proliferate without serum and at the end of the incubation period they would fall below the detection limit of the MTT assay. Therefore, (A) and (B) cannot be compared quantitatively with (C), because the same MOIs actually mean more plaque-forming units per volume of infection medium, and this can affect the efficiency of infection. The experiment was repeated three times with similar results.

cells. To validate this point, we tested four additional nontransformed human cells: BJ and NHFib are fibroblasts derived from skin, HDMECs are endothelial cells, and NHK cells are keratinocytes derived from skin. The cells were infected under normoxic conditions with either AdEHE2F or AdWT at different MOIs. The viability of the cells was analyzed when the monolayers infected with AdWT showed extensive cytopathic effect for each cell type. As shown in Fig. 8, the normal cell populations maintained at least $70 \%$ viability when infected with AdEHE2F, whereas the same amount of AdWT killed virtually all the cells. However, when we performed AdEHE2F infection under hypoxic conditions, the ability of the virus to replicate and kill these cells was greatly activated, reaching levels similar to the wild-type version. This suggests that the attenuation of AdEHE2F in normal cells is specific, and is not simply due to a general reduction of its ability to induce cell death compared with AdWT.

\section{Toxicity of AdEHE2F in mice}

To evaluate whether the specificity observed with AdEHE2F in cultured cells correlated with a reduction in toxicity in vivo, we performed intravenous injections of either AdEHE2F, AdWT, or the E1-deleted adenoviral vector $\mathrm{Ad} \Delta \mathrm{E} 1$. Increasing amounts of viral particles were injected into the retro-orbital plexus of Hsd $n u /+$ mice. We monitored mortality, weight loss, and damage to liver by quantification of the enzyme alanine aminotransferase (ALT). The results are summarized in Fig. 9. We observed that any dose above $1 \times 10^{11}$ particles of AdWT causes death of all the mice 4 days after injection, with severe elevation of ALT levels in the first $48 \mathrm{hr}$. A dose of $0.6 \times 10^{11}$ particles induces a moderate increase in ALT, but no deaths or weight loss occurred. On the other hand, AdEHE2F was well tolerated at $1 \times 10^{11}$ particles, with no mortality and no liver toxicity. This virus was lethal to most of the mice at doses above $4.5 \times 10^{11}$ particles, whereas $2.2 \times 10^{11}$ particles caused the death of only one of four animals. Interestingly, ALT levels in mice that died after AdEHE2F administration were generally lower than those observed for AdWT. In fact, most of the mice died with enzyme levels only twice the upper normal limit (about $120 \mathrm{U} / \mathrm{L}$ ). Finally, $\operatorname{Ad} \Delta \mathrm{E} 1$ showed no signs of toxicity even at the highest dose tested $\left(4.5 \times 10^{11}\right.$ particles $)$. Only a slight increase in ALT levels, still within the physiological range, could be observed. In summary, the toxicity of AdEHE2F is reduced compared with the wild-type virus, but it is somewhat more toxic than a replication-deficient adenoviral vector.

\section{Antitumor effect in vivo}

We evaluated the ability of AdEHT2 and AdEHE2F to inhibit the growth of human breast cancer xenografts established in estrogen-treated nude mice. The tumors were generated by orthotopic injection of BT-474 cells into the mammary fat pad. When they reached an average of $200 \mathrm{~mm}^{3}, 5 \times 10^{8} \mathrm{PFU}$ of virus was injected intratumorally, three consecutive days per week for a total of four weeks. No side effects related to virus administration were observed. Variation in the tumor volume of treated and control mice is shown in Fig. 10. Both AdEHT2 


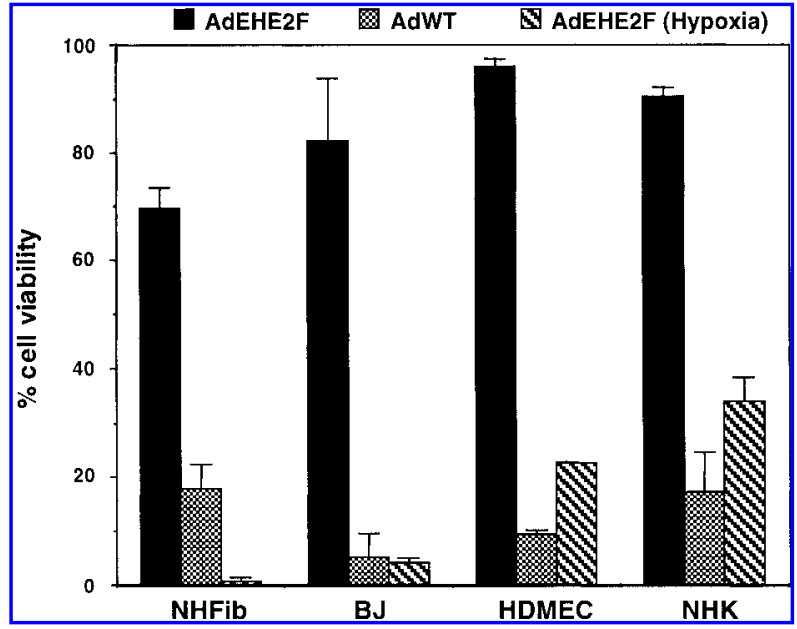

FIG. 8. Cytotoxicity of AdEHE2F in human nontransformed primary cells. BJ and NHFib skin fibroblasts, NHK keratinocytes, and human dermal microvascular endothelial cells (HDMECs) were infected with AdEHE2F (solid columns) and AdWT (cross-hatched columns) with an MOI of $750 \mathrm{PFU} /$ cell for LEHFib, $500 \mathrm{PFU} /$ cell for BJ, and $10 \mathrm{PFU} /$ cell for HDMECs and NHK cells. In addition, the cells were infected with the same amount of AdEHE2F and maintained under hypoxic conditions (hatched columns). Viability was analyzed by MTT assay, 16 days after infection for BJ cells and 9 days after infection for LEHFib cells, HDMECs, and NHK cells. The columns represent the percentage of surviving cells, compared with uninfected cells growing under the same conditions. The experiment was repeated three times with similar results

and AdEHE2F showed similar antitumor effects. The reduction in tumor size compared with the control group was significant after the second week of treatment $(p<0.05)$, and was close to $90 \% 2$ weeks later. Both viruses completely inhibited the growth of tumors. The size of untreated tumors increased more than 4-fold before they reached a plateau, whereas the treated tumors remained smaller than their original size. However, residual lesions could be persistently detected in most of the treated animals.

\section{DISCUSSION}

The ability of CRADs to complete the lytic cycle of adenovirus makes them a promising platform to develop new viral or gene therapy strategies against cancer. However, every step of this cycle is subjected to complex regulation that is still not fully understood. The degree and time of expression of viral proteins, as well as their repertoire of interactions with cellular counterparts, need to be compatible with productive infection. When E1A and E1B genes of adenovirus are mutated or deleted to make the replication of the virus tumor specific (type 1 CRADs), its performance can decrease because some basic functions of the proteins can be affected. On the other hand, when the promoters for the E1A and E4 genes are replaced by tumor or tissue-specific promoters (type 2 CRADs), it is difficult to predict what impact this will have on replication of the virus. The combination of promoters used in this study can pro- vide some information about the latter question. Our results support the notion that a tight regulation of the E1A region is critical for the control of adenovirus replication. This can be achieved by using an artificial, minimal promoter that contains only the response elements required for its function, in this case the EREs and HREs. This minimizes the possibility that the promoter can be activated in certain undesirable cell types or situations that are difficult to test by transient transfections with reporter plasmids. Both AdEHT2 and AdEHE2F showed a good activation of E1A expression by hypoxia in different cell lines, or by estrogens in $\mathrm{ER}^{+}$cells. This correlated well with increased cytotoxicity under the same circumstances. In solid tumors, the activation of viral replication in hypoxic areas can create multiple sites in which the concentration of the virus is high. This could cause destruction of surrounding areas of the tumor, even if they are not hypoxic, until the titers of virus decrease radially into the normoxic areas. This could happen independently of the ER status of the tumor. However, in the case of an $\mathrm{ER}^{+}$ tumor, like many breast cancers, replication of these CRADs would be activated beyond the hypoxic areas. Again, this may not require that every single cell in the tumor be $\mathrm{ER}^{+}$. In addition, the use of a promoter activated by HIF can provide tumor specificity by itself, because overexpression of this transcription factor may be associated with the transformed phenotype of some cancer cells (Bos et al., 2001).

For several reasons, analyzing the function of the promoters used in the E4 region of these viruses is more complex. First, both of them contain binding sites for transcription factors

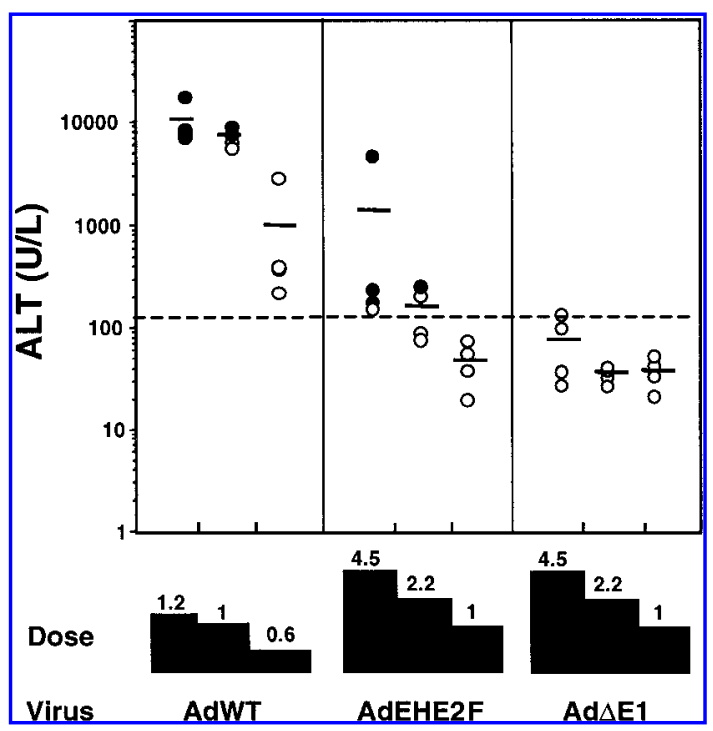

FIG. 9. Toxicity of AdEHE2F. Mice ( $n=4$ per group) were injected intravenously with increasing amounts of either AdWT (left), AdEHE2F (center), or $\mathrm{Ad} \Delta \mathrm{E} 1$ (right). The doses $\left(\times 10^{11}\right.$ particles) are indicated below each group. Shown are the serum levels of alanine aminotransferase (ALT) in units per liter for every animal, analyzed $48 \mathrm{hr}$ after infection. The solid columns indicate the mean value for each group. Open circles represent mice that survived 10 days after infection, whereas solid circles indicate mice that died, usually 4 days after infection. The discontinuous line indicates the maximum normal value for ALT (approximately $120 \mathrm{U} / \mathrm{L}$ ). 


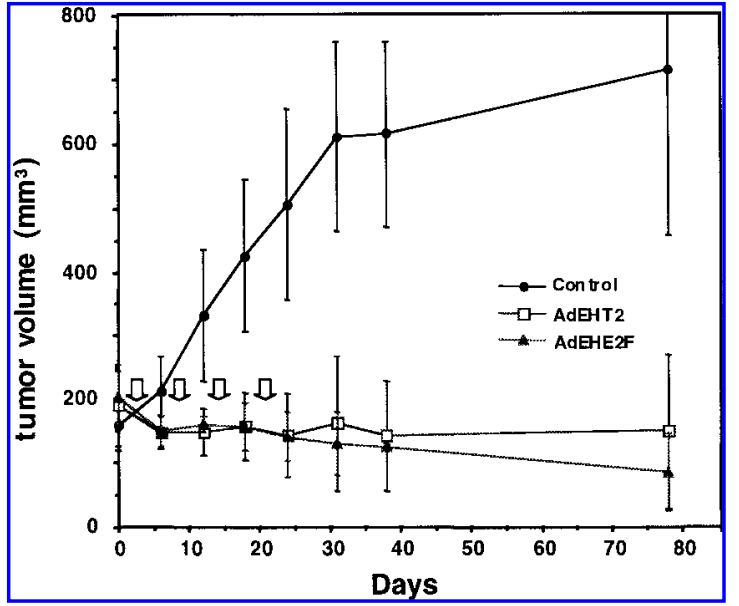

FIG. 10. Antitumor effect of AdEHT2 and AdEHE2F in vivo. Human tumor xenografts were established in estrogen-treated female nude mice by injection of BT-474 cells into the mammary fat pads. Mice were injected intratumorally with either vehicle alone (solid circles), $5 \times 10^{8} \mathrm{PFU}$ of AdEHT2 (open squares), or $5 \times 10^{8}$ PFU of AdEHE2F (solid triangles) $(n=$ $5)$. The treatment was administered for three consecutive days per week during the first 4 weeks (open arrows), and then the mice were left untreated. The significance of the differences observed between control and treated groups was analyzed by Student $p$ test.

whose expression can be activated under different circumstances. The core hTERT promoter used in AdEHT2 contains AP2, E-box, Myc, and Sp1 binding sites (Horikawa et al., 1999; Takakura et al., 1999; Wick et al., 1999). The E2F-1 promoter used in AdEHE2F contains MBF-1, Sp1, NF- $\kappa$ B, and E2F binding sites (Hsiao et al., 1994; Neuman et al., 1994). Second, both promoters can be potentially stimulated by E1A, either directly or as a consequence of the activation of the cell cycle. Finally, although the E4 region is believed to be necessary for efficient virus replication because the E4-deleted adenoviruses are attenuated, it is possible that low levels of expression of the E4 open reading frames (ORFs) can support replication if the rest of the transcription units of the virus are activated. A combination of these facts might explain the observation that the AdEHT2 virus was not attenuated in the telomerase-negative IMR-90 cells when they were infected under hypoxic conditions. Similar results were obtained with Saos-2 cells, a human osteosarcoma cell line that shows low telomerase activity (Zhang et al., 2000; and data not shown). Although previous characterization of the hTERT core promoter suggested that it was able to provide negative regulation in telomerase-negative cells (Takakura et al., 1999), it is possible that some key silencer is missing in this short fragment. Therefore, we cannot rule out the possibility that a longer regulatory region could restrict replication of the virus.

Although most of the previous considerations also apply to the E2F-1 promoter, the fact is that we saw attenuation of the AdEHE2F virus in cells with a low level of E2F activity, such as nontransformed cells (IMR-90) maintained in serum-free medium. This could be a useful feature of this CRAD, because these conditions apply to most somatic cells. The majority of cells in the connective tissue, for instance, are not hypoxic and show low levels of E2F transcription factors because they do not proliferate continuously. Therefore, it might work as a barrier for the proliferation of AdEHE2F. Many cells in a solid tumor such as breast cancer are also quiescent, but if they are infected by AdEHE2F, as long as they are hypoxic or express $\mathrm{ER}$, the E1A region of the virus will be expressed, and this may activate the E4 region. Using the modified adenovirus backbone that we have constructed, different combinations of promoters can be tested in order to optimize the CRADs. The EREs can be avoided to prevent possible side effects in normal $\mathrm{ER}^{+}$ tissues; a mutated E1A that does not bind to $\mathrm{pRB}$ can be tested to avoid activation of the E4 region (Johnson et al., 2002); artificial minimal promoters can be placed in the $\mathrm{E} 4$ region to achieve a genuine second level of regulation, and newly characterized tumor-specific promoters for particular malignancies can be readily incorporated in the system. The goal in the design of CRADs is to achieve an optimum balance between attenuation in normal tissues and full cytolytic activity in tumors. All the measures described above can contribute to achieve this goal. In the case of AdEHT2 and AdEHE2F, the relatively low expression of $\mathrm{E} 4$ proteins might be the reason why these viruses are less efficient than wild type. Still, the E2F-1 promoter used in AdEHE2F contributed to the attenuation of the virus in normal cells. Combining this promoter with HREs might enhance the expression of E4 under hypoxic conditions, and increase the cytotoxicity of the virus without affecting its regulation. Finally, the new CRADs that we describe here have shown antitumor activity in vivo. They were able to block the growth of human tumor xenografts in nude mice, but they were not able to completely eradicate them in most of the animals. There may be physical barriers that limit the dissemination of the virus in the tumor mass. This problem should be addressed in order to enhance the oncolytic potential of these agents. AdEHE2F was well tolerated when administered intratumorally at doses that achieved a significant antitumor effect. It is less toxic than the wild-type adenovirus after intravenous administration, in terms of both mortality and liver toxicity. In fact, most of the mice that died from high doses of AdEHE2F had only moderate elevations of the ALT enzyme. At present, it is not clear if this reflects the existence of a different dose-limiting target organ. Despite the tight regulation of E1A expression observed in cell culture assays, this virus was still more toxic than a conventional E1-deleted, replication-deficient adenoviral vector. Strategies to achieve targeted infection, combined with the regulation of viral replication, will be necessary to obtain an optimum balance between safety and efficacy of CRADs.

\section{ACKNOWLEDGMENTS}

We thank Stefan Stoll and Jacques Nor for help with the primary cells, Laurie Kittl for correction of the manuscript, and in-Kyung Park for helpful discussions. This work was supported by NIH grants CA 75136 and CA 67140.

\section{NOTE ADDED IN PROOF}

During the preparation and evaluation of this manuscript, two new CRADs using the E2F-1 promoter have been described by 
independent groups (Johnson et al., 2002; Tsukuda et al., 2002). Their results strongly support the use of this promoter to achieve cancer-specific replication of adenoviruses.

\section{REFERENCES}

ADACHI, Y., REYNOLDS, P.N., YAMAMOTO, M., WANG, M., TAKAYAMA, K., MATSUBARA, S., MURAMATSU, T., and CURIEL, D.T. (2001). A Midkine promoter-based conditionally replicative adenovirus for treatment of pediatric solid tumors and bone marrow tumor purging. Cancer Res. 61, 7882-7888.

ALEMANY, R., BALAGUE, C., and CURIEL, C.T. (2000). Replicative adenoviruses for cancer therapy. Nat. Biotechnol. 18, 723-727. BIEDERER, C., RIES, S., BRANDTS, C.H., and MCCORMICK, F. (2002). Replication-selective viruses for cancer therapy. J. Mol. Med. 80, 163-175.

BISCHOFF, J., KIRN, D., WILLIAMS, A., HEISE, C., HORN, S., MUNA, M., NG, L., NYE, J.A., SAMPSON-JOHANNES, A., FATTAEY, A., and MCCORMICK, F. (1996). An adenovirus mutant that replicates selectively in p53-deficient human tumor cells. Science 274, 373-376.

BOS, R., ZHONG, H., HANRAHAN, C.F., MOMMERS, E.C.M., SEMENZA, G.L., PINEDO, H.M., ABELOFF, M.D., SIMONS, J.W., VAN DIEST, P.J., and VAN DER WALL, E. (2001). Levels of hypoxia-inducible factor $1 \alpha$ during breast carcinogenesis. J. Natl. Cancer Inst. 93, 309-314.

BRANTON, P.E., and ROOPCHAND, D.E. (2001). The role of adenovirus E4orf4 protein in viral replication and cell killing. Oncogene 20, 7855-7865.

BRUGGER, W., BUHRING, H.J., GRUNEBACH, F., VOGEL,W., KAUL, S., MULLER, R., BRUMMENDORF, T.H., ZIEGLER, B.L., RAPPOLD, I., BROSSART, P., SCHEDING, S., and KANZ, L. (1999). Expression of MUC-1 epitopes on normal bone marrow: Implications for the detection of micrometastatic tumor cells. J. Clin. Oncol. 17, 1535-1544.

DACHS, G.U., PATTERSON, A.V., FIRTH, J.D., RATCLIFFE, P.J., TOWNSEND, K.M., STRATFORD, I.J., and HARRIS, A.L. (1997). Targeting gene expression to hypoxic tumor cells. Nat. Med. 3, $515-520$.

DORONIN, K., KUPPUSWAMY, M., TOTH, K., TOLLEFSON, A.E., KRAJCSI, P., KROUGLIAK, V., and WOLD, W.S.M. (2001). Tissue-specific, tumor-selective, replication-competent adenovirus vector for cancer gene therapy. J. Virol. 75, 3314-3324.

EKENA, K., KATZENELLENBOGEN, J.A., and KATZENELLENBOGEN, B.S. (1998). Determinants of ligand specificity of estrogen receptor- $\alpha$ : Estrogen versus androgen discrimination. J. Biol. Chem. 273, 693-699.

FALGOUT, B., and KETNER, G. (1987). Adenovirus early region 4 is required for efficient virus particle assembly. J. Virol. 61, 3759-3768.

FLINT, J., and SHENK, T. (1997). Viral transactivating proteins. Annu. Rev. Genet. 31, 177-212.

FUERER, C., and IGGO, R. (2002). Adenoviruses with Tcf binding sites in multiple early promoters show enhanced selectivity for tumour cells with constitutive activation of the wnt signalling pathway. Gene Ther. 9, 270-281.

FUEYO, J., GOMEZ-MANZANO, C., ALEMANY, R., LEE, P.S., MCDONNELL, T.J., MITLIANGA, P., SHI, Y.X., LEVIN, V.A.,YUNG, W.K., and KYRITSIS, A.P. (2000). A mutant oncolytic adenovirus targeting the $\mathrm{Rb}$ pathway produces anti-glioma effect in vivo. Oncogene 19, 2-12.

GOOD, L., DIMRI, G.P., CAMPISI, J., and CHEN, K.Y. (1996). Regulation of dihydrofolate reductase gene expression and E2F components in human diploid fibroblasts during growth and senescence. $\mathrm{J}$. Cell. Physiol. 168, 580-588.
GREIDER, C.W. (1996). Telomere length regulation. Annu Rev. Biochem. 65, 337-365.

HALBERT, D.N., CUTT, J.R., and SHENK, T. (1985). Adenovirus early region 4 encodes functions required for efficient DNA replication, late gene expression, and host cell shutoff. J. Virol. 56, 250 257.

HALLENBECK, P.L., CHANG, Y., HAY, C., GOLIGHTLY, D., STEWART, D., LIN, J., PHIPPS, S., and CHIANG, Y.L. (1999). A novel tumor-specific replication-restricted adenoviral vector for gene therapy of hepatocellular carcinoma. Hum. Gene Ther. 10, 17211733 .

HARLE-BACHOR, C., and BOUKAMP, P. (1996). Telomerase activity in the regenerative basal layer of the epidermis in human skin and in immortal and carcinoma-derived skin keratinocytes. Proc. Natl. Acad. Sci. U.S.A. 93, 6476-6481.

HEISE, C., HERMISTON, T., JOHNSON, L., BROOKS, G., SAMPSON-JOHANNES, A., WILLIAMS, A., HAWKINS, L., and KIRN, D. (2000). An adenovirus E1A mutant that demonstrates potent and selective systemic anti-tumoral efficacy. Nat. Med. 6, 1134-1139.

HERNANDEZ-ALCOCEBA, R., PIHALJA, M., WICHA, M.S., and CLARKE, M.F. (2000). A novel, conditionally replicative adenovirus for the treatment of breast cancer that allows controlled replication of E1a-deleted adenoviral vectors. Hum. Gene Ther. 11, 2009-2024.

HERNANDEZ-AlCOCEBA, R., PIHALJA, M., NUNEZ, G., and CLARKE, M.F. (2001). Evaluation of a new dual-specificity promoter for selective induction of apoptosis in breast cancer cells. Cancer Gene Ther. 8, 298-307.

HORIKAWA, I., CABLE, P.L., AFSHARI, C., and BARRETT, J.C. (1999). Cloning and characterization of the promoter region of human telomerase reverse transcriptase gene. Cancer Res. 59, 826-830.

HSIAO, K., MCMAHON, S.L., and FARNHAM, P.J. (1994). Multiple DNA elements are required for the growth regulation of the mouse E2F1 promoter. Genes Dev. 8, 1526-1537.

HUANG, L.E., GU, J., SCHAU, M., and BUNN, H.F. (1998). Regulation of hypoxia-inducible factor $1 \alpha$ is mediated by an $\mathrm{O}_{2}$-dependent degradation domain via the ubiquitin-proteasome pathway. Proc. Natl. Acad. Sci. U.S.A. 95, 7987-7992.

JOHNSON, D.G., OHTANI, K., and NEVINS, J.R. (1994). Autoregulatory control of E2F1 expression in response to positive and negative regulators of cell cycle progression. Genes Dev. 8, 1514-1525. JOHNSON, L., SHEN, A., BOYLE, L., KUNICH, J., PANDEY, K., LEMMON, M., HERMISTON, T., GIEDLIN, M., MCCORMICK, F., and FATTAEY, A. (2002). Selective replicating adenoviruses targeting deregulated E2F activity are potent, systemic antitumor agents. Cancer Cell 1, 325-337.

KIRN, D. (2001). Clinical research results with d11520 (Onyx-015), a replication-selective adenovirus for the treatment of cancer: What have we learned? Gene Ther. 8, 89-98.

KOMATA, T., KONDO, Y., KANZAWA, T., HIROHATA, S., KOGA, S., SUMIYOSHI, H., SRINIVASULA, S.M., BARNA, B.P., GERMANO, I.M., TAKAKURA, M., INOUE, M., ALNEMRI, E.S., SHAY, J.W., KYO, S., and KONDO, S. (2001). Treatment of malignant glioma cells with the transfer of constitutively active caspase6 using the human telomerase catalytic subunit (human telomerase reverse transcriptase) gene promoter. Cancer Res. 61, 5796-5802. KRUYT, F., and CURIEL, D.T. (2002). Toward a new generation of conditionally replicating adenoviruses: Pairing tumor selectivity with maximal oncolysis. Hum. Gene Ther. 13, 485-495.

KURIHARA, T., BROUGH, D.E., KOVESDI, I., and KUFE, D.W. (2000). Selectivity of a replication-competent adenovirus for human breast carcinoma cells expressing the MUC-1 antigen. J. Clin. Invest. 106, 763-771.

LAUGHNER, E., TAGHAVI, P., CHILES, K., MAHON, P.C., and SEMENZA, G.L. (2001). Her2 (neu) signaling increases the rate of hypoxia-inducible factor $1 \alpha(\mathrm{HIF}-1 \alpha)$ synthesis: Novel mechanism 
for HIF-1-mediated vascular endothelial growth factor expression. Mol. Cell. Biol. 21, 3995-4004.

MAJUMDAR, A.S., HUGHES, D.E., LICHTSTEINER, S.P., WANG, Z., LEBKOWSKI, J.S., and VASSEROT, A.P. (2001). The telomerase reverse transcriptase promoter drives efficacious tumor suicide gene therapy while preventing hepatotoxicity encountered with constitutive promoters. Gene Ther. 8, 568-578.

MATSUBARA, S., WADA, Y., GARDNER, T.A., EGAWA, M., PARK, M., HSIEH, C., ZHAU, H.E., KAO, C., KAMIDONO, S., GILLENWATER, J.Y., and CHUNG, K.W.K. (2001). A conditional replication-competent adenoviral vector, Ad-OC-E1a, to cotarget prostate cancer and bone stroma in an experimental model of androgen-independent prostate cancer bone metastasis. Cancer Res. 61, 6012-6019.

MEYERSON, M., COUNTER, C.M., EATON, E.N., ELLISEN, L.W., STEINER, P., DICKINSON-CADDLE, S., ZIAUGRA, L., BEIJERSBERGEN, R.L, DAVIDOFF, M.J., LIU, Q., BACCHETTI, S., HABER, D.A., and WEINBERG, R.A. (1997). HEST2, the putative human telomerase catalytic subunit gene, is up-regulated in tumor cells and during immortalization. Cell 90, 785-795.

MIZUGUCHI, H., and KAY, M.A. (1998). Efficient construction of a recombinant adenovirus vector by an improved in vitro ligation method. Hum. Gene Ther. 20, 2577-2583.

MOULDER, S.L., YAKES, F.M., MUTHUSWAMY, S.K., BIANCO, R., SIMPSON, J.F., and ARTEAGA, C.L. (2001). Epidermal growth factor receptor (HER1) tyrosine kinase inhibitor ZD1839 (Iressa) inhibits HER2/neu (erbB2)-overexpressing breast cancer cells in vitro and in vivo. Cancer Res. 61, 8887-8895.

NEUMAN, E., FLEMINGTON, E.K, SELLERS, W.R., and KAELIN, W.G. (1994). Transcription of the E2F-1 gene is rendered cell cycle dependent by E2F DNA-binding sites within its promoter. Mol. Cell. Biol. 14, 6607-6615.

PARR, M.J., MANOME, Y., TANAKA, T., WEN, P., KUFE, D.W., KAELIN, W.G., and FINE, H.A. (1997). Tumor-selective transgene expression in vivo mediated by an E2F-responsive adenoviral vector. Nat. Med. 3, 1145-1149.

POLAGER, S., KALMA, Y., BERKOVICH, E., and GINSBERG, D. (2002). E2Fs up-regulate expression of genes involved in DNA replication, DNA repair and mitosis. Oncogene 21, 437-446.

RAMACHANDRA, M., RAHMAN, A., ZOU, A., VAILLANCOURT, M., HOWE, J.A., ANTELMAN, D., SUGARMAN, B., DEMERS, G.W., ENGLER, H., JOHNSON, D., and SHABRAM, P. (2001). Re-engineering adenovirus regulatory pathways to enhance oncolytic specificity and efficacy. Nat. Biotechnol. 19, 1035-1041.

RIES, S.J., BRANDTS, C.H., CHUNG, A.S., BIEDERER, C.H., HANN, B.C., LIPNER, E.M., MCCORMICK, F., and KORN, W.M. (2000). Loss of p14 ${ }^{A R F}$ in tumor cells facilitates replication of the adenovirus mutant d11520 (ONYX-015). Nat. Med. 6, 1128-1133.

SELLERS, W.R., RODGERS, J.W., and KAELIN, W.G. (1995). A potent transrepression domain in the retinoblastoma protein induces a cell cycle arrest when bound to E2F sites. Proc. Natl. Acad. Sci. U.S.A. 92, 11544-11548.

SHENK, T. (1996). Adenoviridae: The viruses and their replication. In Fields Virology. B.N. Fields, D.M. Knipe, and P.M. Howley, eds. (Lippincott-Raven, Philadelphia, PA) pp. 2111-2147.

TAKAKURA, M., KYO, S., KANAYA, T., HIRANO, H., TAKEDA, J., YUTSUDO, M., and INOUE, M. (1999). Cloning of human telomerase catalytic subunit (hTERT) gene promoter and identification of proximal core promoter sequences essential for transcriptional activation in immortalized and cancer cells. Cancer Res. 59, 551-557.

TAlKS, K.L., TURLEY, H., GATTER, K.C., MAXWELL, P.H.,
PUGH, C.W., RATCLIFFE, P.J., and HARRIS, A.L. (2000). The expression and distribution of the hypoxia-inducible factors HIF- $1 \alpha$ and HIF- $2 \alpha$ in normal human tissues, cancers, and tumor-associated macrophages. Am. J. Pathol. 157, 411-421.

TAUBER, B., and DOBNER, T. (2001). Adenovirus early E4 genes in viral oncogenesis. Oncogene 20, 7847-7854.

TSUKUDA, K., WIEWRODT, R., MOLNAR-KIMBER, K., JOVANOVIC, V.P., and AMIN, K.M. (2002). An E2f-responsive replication-selective adenovirus targeted to the defective cell cycle in cancer cells: Potent antitumoral efficacy but no toxicity to normal cell. Cancer Res. 62, 3438-3447.

ULANER, G.A., HU, J.F., VU, T.H., GUIDICE, L.C., and HOFFMAN, A.R. (1998). Telomerase activity in human development is regulated by human telomerase reverse transcriptase (hTERT) transcription and by alternate splicing of hTERT transcripts. Cancer Res. 58, 41684172 .

VALAVAARA, R. (1997). Reliability of estrogen receptors in predicting response to antiestrogens. Oncology 11, 14-18.

VASSAUX, G., HURST, H.C., and LEMOINE, N.R. (1999). Insulation of a conditionally expressed transgene in an adenoviral vector. Gene Ther. 6, 1192-1197.

WICK, M., ZUBOV, D., and HAGEN, G. (1999). Genomic organization and promoter characterization of the gene encoding the human telomerase reverse transcriptase (hTERT). Gene 232, 97-106.

YANG, C., YOU, L., UEMATSU, K., YEH, C., MCCORMICK, F., and JABLOND, D.M. (2001). p14 ${ }^{A R F}$ modulates the cytolytic effect of ONYX-015 in mesothelioma cells with wild-type p53. Cancer Res. 61, 5959-5963.

YU, D., SAKAMOTO, G.T., and HENDERSON, D.R. (1999). Identification of the transcriptional regulatory sequences of human kallikrein 2 and their use in the construction of calydon virus 764, an attenuated replication competent adenovirus for prostate cancer therapy. Cancer Res. 59, 1498-1504.

ZHANG, A., ZHENG, C., LINDVALL, C., HOU, M., EKEDAHL, J., LEWENSOHN, R., YAN, Z., YANG, X., HENRIKSSON, M., BLENNOW, E., NORDENSKJOLD, M., ZETTERBERG, A., BJORKHOLM, M., GRUBER, A., and XU, D. (2000). Frequent amplification of the telomerase reverse transcriptase gene in human tumors. Cancer Res. 60, 6230-6235.

ZHONG, H., DE MARZO, A.M., LAUGHNER, E., LIM, M., HILTON, D.A., ZAGZAG, D., BUECHLER, P., ISAACS, W.B., SEMENZA, G.L., and SIMONS, J.W. (1999). Overexpression of hypoxia-inducible factor $1 \alpha$ in common human cancers and their metastases. Cancer Res. 15, 5830-5835.

Address reprint requests to: Dr. Michael F. Clarke Department of Internal Medicine-Hematology/Oncology University of Michigan Comprehensive Cancer Center 1500 E. Medical Center Drive 4310 CCGC/0936 Ann Arbor, MI 48109

E-mail: mclarke@umich.edu

Received for publication April 11, 2002; accepted after revision August 1, 2002.

Published online: September 3, 2002. 


\section{This article has been cited by:}

1. J. Ma, X. He, W. Wang, Y. Huang, L. Chen, W. Cong, J. Gu, H. Hu, J. Shi, L. Li, C. Su. 2009. E2F Promoter-Regulated Oncolytic Adenovirus with p16 Gene Induces Cell Apoptosis and Exerts Antitumor Effect on Gastric Cancer. Digestive Diseases and Sciences 54:7, 1425-1431. [CrossRef]

2. Sergia Bortolanza, Maria Bunuales, Itziar Otano, Gloria Gonzalez-Aseguinolaza, Carlos Ortiz-de-Solorzano, Daniel Perez, Jesus Prieto, Ruben Hernandez-Alcoceba. 2009. Treatment of Pancreatic Cancer With an Oncolytic Adenovirus Expressing Interleukin-12 in Syrian Hamsters. Molecular Therapy 17:4, 614-622. [CrossRef]

3. S Bortolanza, M Bunuales, P Alzuguren, O Lamas, R Aldabe, J Prieto, R Hernandez-Alcoceba. 2009. Deletion of the E3-6.7K/gp19K region reduces the persistence of wild-type adenovirus in a permissive tumor model in Syrian hamsters. Cancer Gene Therapy . [CrossRef]

4. Joanne Morrison, Simon S. Briggs , Nicola K. Green, Clemens Thoma, Kerry D. Fisher, Sean Kehoe , Leonard W. Seymour . 2009. Cetuximab Retargeting of Adenovirus via the Epidermal Growth Factor Receptor for Treatment of Intraperitoneal Ovarian CancerCetuximab Retargeting of Adenovirus via the Epidermal Growth Factor Receptor for Treatment of Intraperitoneal Ovarian Cancer. Human Gene Therapy 20:3, 239-251. [Abstract] [PDF] [PDF Plus] [Supplementary material]

5. N Lei, F B Shen, J H Chang, L Wang, H Li, C Yang, J Li, D C Yu. 2009. An oncolytic adenovirus expressing granulocyte macrophage colony-stimulating factor shows improved specificity and efficacy for treating human solid tumors. Cancer Gene Therapy 16:1, 33-43. [CrossRef]

6. M. Bazan-Peregrino , R.C. Carlisle , R. Hernandez-Alcoceba , R. Iggo , K. Homicsko , K.D. Fisher , G. Halldén , V. Mautner, Y. Shen , L.W. Seymour . 2008. Comparison of Molecular Strategies for Breast Cancer Virotherapy Using Oncolytic AdenovirusComparison of Molecular Strategies for Breast Cancer Virotherapy Using Oncolytic Adenovirus. Human Gene Therapy 19:9, 873-886. [Abstract] [PDF] [PDF Plus]

7. Dirk M. Nettelbeck. 2008. Cellular genetic tools to control oncolytic adenoviruses for virotherapy of cancer. Journal of Molecular Medicine 86:4, 363-377. [CrossRef]

8. Dennis Hoffmann, Wibke Bayer, Albert Heim, Anja Potthoff, Dirk M Nettelbeck, Oliver Wildner. 2008. Evaluation of Twenty-One Human Adenovirus Types and One Infectivity-Enhanced Adenovirus for the Treatment of Malignant Melanoma. Journal of Investigative Dermatology 128:4, 988-998. [CrossRef]

9. Dennis Hoffmann, Bernhard Meyer, Oliver Wildner. 2007. Improved glioblastoma treatment with Ad5/35 fiber chimeric conditionally replicating adenoviruses. The Journal of Gene Medicine 9:9, 764-778. [CrossRef]

10. D Hoffmann, O Wildner. 2007. Comparison of herpes simplex virus- and conditionally replicative adenovirus-based vectors for glioblastoma treatment. Cancer Gene Therapy 14:7, 627-639. [CrossRef]

11. M. J. Calzada, L. Peso. 2007. Hypoxia-inducible factors and cancer. Clinical and Translational Oncology 9:5, 278-289. [CrossRef]

12. Hong Jiang, Frank McCormick, Frederick F Lang, Candelaria Gomez-Manzano, Juan Fueyo. 2006. Oncolytic adenoviruses as antiglioma agents. Expert Review of Anticancer Therapy 6:5, 697-708. [CrossRef]

13. Lawrence S Young, Peter F Searle, David Onion, Vivien Mautner. 2006. Viral gene therapy strategies: from basic science to clinical application. The Journal of Pathology 208:2, 299-318. [CrossRef]

14. M Kuppuswamy, J F Spencer, K Doronin, A E Tollefson, W S M Wold, K Toth. 2005. Oncolytic adenovirus that overproduces ADP and replicates selectively in tumors due to hTERT promoter-regulated E4 gene expression. Gene Therapy 12:22, 1608-1617. [CrossRef]

15. Yuqiao Shen, Neil Senzer, John Nemunaitis. 2005. Individualised cancer therapeutics: dream or reality? Therapeutics construction. Expert Opinion on Biological Therapy 5:11, 1427-1441. [CrossRef]

16. R Argnani, M Lufino, M Manservigi, R Manservigi. 2005. Replication-competent herpes simplex vectors: design and applications. Gene Therapy 12, S170-S177. [CrossRef] 
17. Syed A Hussain, Daniel H Palmer, Sarah Moon, Daniel W Rea. 2005. Endocrine therapy and other targeted therapies for metastatic breast cancer. Expert Review of Anticancer Therapy 4:6, 1179-1195. [CrossRef]

18. Shinae Kizaka-Kondoh, Masahiro Inoue, Hiroshi Harada, Masahiro Hiraoka. 2004. Tumor hypoxia: A target for selective cancer therapy. Cancer Science 94:12, 1021-1028. [CrossRef]

19. Dirk M. Nettelbeck. 2003. Virotherapeutics: conditionally replicative adenoviruses for viral oncolysis. Anti-Cancer Drugs 14:8, 577-584. [CrossRef]

20. Dawn E. Post , Fadlo R. Khuri , Jonathan W. Simons, Erwin G. van Meir . 2003. Replicative Oncolytic Adenoviruses in Multimodal Cancer RegimensReplicative Oncolytic Adenoviruses in Multimodal Cancer Regimens. Human Gene Therapy 14:10, 933-946. [Abstract] [PDF] [PDF Plus] 